\title{
IMPACTS OF HALOKINESIS IN SEISMIC INTERPRETATION AND GENERATION OF THE TOP SALT SURFACE IN A DISTAL PORTION OF THE SANTOS BASIN, BRAZIL
}

\author{
Wagner M. Lupinacci ${ }^{1}$, Rafael P. C. Viana ${ }^{1}$, Danilo J. A. Ferreira ${ }^{1,2}$, Igor de A. Neves ${ }^{1}$, João Paulo R. \\ Zambrini ${ }^{1}$, Maria 0. Azul ${ }^{3}$, André L. Ferrari ${ }^{1}$ and Luiz Antônio P. Gamboa ${ }^{1}$
}

\begin{abstract}
Studies on evaporitic rocks are of great importance for the oil and gas industry as they can create traps and seals for the hydrocarbon accumulations. Also, salt high ductility allows the formation of complex structures associated with halokinesis posing thus major challenges for imaging the rocks at their flanks and below the structures. This paper discusses the effects of salt tectonics on post-salt layers and the difficulties in interpreting the top salt surface in a particularly complex area of the Santos Basin. The available seismic and migration velocity model data are from an area located in the distal portion of the Santos Basin where the existing salt structures had a profound effect on the post-salt layers. Complex salt structures were formed in this area due to the intrinsic characteristics of salt rocks as it flew away from the terrigenous depocenters, pushed in the Atlantic Ocean realms. Structures such as overhangs are common and sometimes difficult to be mapped. Their geometry generates multiple points with the same latitude and longitude, but at different depths as they are interpreted and thus represent a challenge for current surface interpolation algorithms. A workflow is proposed to optimize multi- $z$ surfaces generation from the top of the salt layer from the interpretation this surface in conjunction with the analysis of the migration velocity model. Finally, a zonation map of the salt walls, mini-basins, salt domes, overhang and salt window in the region is presented.
\end{abstract}

Keywords: halokinesis, seismic interpretation, salt structures zonation, top of the salt layer.

RESUMO. Estudos sobre rochas evaporíticas são de grande importância para a indústria de petróleo e gás, pois podem criar armadilhas e selos para 0 acúmulo de hidrocarbonetos. Além disso, a alta ductilidade do sal permite a formação de estruturas complexas associadas à halocinese, representando assim grandes desafios para a visualização das rochas em seus flancos e abaixo das estruturas salinas. Este artigo discute os efeitos da tectônica de sal nas camadas do pós-sal e as dificuldades em interpretar a superfície do topo do sal em uma área particularmente complexa da Bacia de Santos. Os dados sísmicos e de poços utilizados são de uma área localizada na porção distal da Bacia de Santos, onde as estruturas de sal existentes tiveram um grande efeito nas camadas do pós-sal. Estruturas complexas de sal foram formadas nesta área devido às características intrínsecas das rochas salinas à medida que se distanciaram dos depocentros terrígenas, empurradas para o domínio do Oceano Atlântico. Estruturas como overhangs são comuns e às vezes difíceis de serem mapeadas. Sua geometria gera múltiplos pontos com a mesma latitude e longitude, mas em profundidades diferentes conforme são interpretadas e, portanto, representam um desafio para os algoritmos existentes de interpolação de superfície. Um fluxo de trabalho é proposto para otimizar a geração de superfícies multi-z do topo da camada de sal a partir da interpretação sísmica desta superfície em conjunto com a análise do modelo de velocidade de migração. Por fim, é apresentado um zoneamento das muralhas de sal, mini-bacias, domos de sal e janela de sal na área de estudo.

Palavras-chave: halocinese, interpretação sísmica, zoneamento das estruturas do sal, topo da camada do sal.

\footnotetext{
${ }^{1}$ Universidade Federal Fluminense, Department Geology and Geophysics (GIECAR), Av. General Tavares de Souza, 24120-346, Niterói, RJ, Brazil - E-mails: wagnerlupinacci@id.uff.br, rafaelcherenev@gmail.com, dferreira8@slb.com, joaozambrini@id.uff.br

2Schlumberger, Software Integrated Solutions, Av. República do Chile 330, RJ, 20031-170, Brazil - E-mail: dferreira8@slb.com

${ }^{3}$ Petrogal Brasil S.A. Av. República do Chile, 330 - Centro, 20031-170, Rio de Janeiro, RJ, Brazil - E-mail: mariaolhoazul@petrogalbrasil.com
} 


\section{INTRODUCTION}

The evaporites are rocks formed, generally, in environments with low terrigenous sedimentary input, submitted to dry climates and high evaporation rates. The rocks formed by salts are different from the most rocks, as they have both solid and liquid state characteristics. Evaporite rocks can be considered as mobile rocks because they move very easily, both chemically in aqueous solution and physically in solid flow (Mohriak et al., 2008).

Formation of evaporites can occur in both marine and continental environments. In marine marginal configuration, the evaporites are formed in sabkha and saline plains. In continental configuration, the saline lakes can precipitate thick layers of salts (da Silva et al., 2018).

In the Santos Basin, the evaporitic rocks were deposited in a transitional environment, during the Aptian and define the Ariri Formation. The Florianópolis High and the São Paulo Ridge acted as the barrier to oceanic water circulation and in addiction to an arid climate created conditions for the deposition of a thick evaporite sequence (Karner \& Gambôa, 2007). Its main lithological constituents are halite and anhydrite. However, thinner layers of more soluble salts, such as, tachyhydrite, carnallite and, locally, sylvite, also occur. Its lower limit is given by the contact with the carbonates from the Barra Velha Formation and its upper limit is given by the contact with open marine carbonates from the Guarujá Formation (Moreira et al., 2007).

Halokinesis, or salt tectonics, is produced by the movement of salt bodies caused through gravity action over evaporitic rocks, which are less resistant, presenting low viscosity. Salt deformation causes a series of structures related to its flow towards basin distal portions and in its ascension to lower lithostatic pressure levels (Jackson \& Hudec, 2017).

Several studies in the Santos and Campos Basins and their African margin counterparts aimed to analyze the structures generated by the halokinesis and its role in gravitation tectonism during drift phase (Demercian et al., 1993; Modica \& Brush, 2004; Gamboa et al., 2008; Mohriak et al., 2009; Davison et al., 2012; Guerra \& Underhill, 2012; Dooley et al., 2015; Jackson et al., 2015; Alves et al., 2017). In general, the structures commonly found in dipping basinwards are, initially, pillows and anticlines, which gradate to locations with predominance of several forms of diapirism and, finally, in the more distal zones allochthonous salts occur.

Davison et al. (2012) proposed, based on observations of salt deformation in seismic lines along the Santos Basin, a zonation of evaporite layer rheological behavior where: in the proximal portions of the basin, features associated with extensional tectonics predominate, with normal faulting presence and regularly experiencing a translational domain which changes to features linked to compression and, in the deeper regions, there is a zone where salt walls and allochthonous structures occur with the existence of prominent thrust faults.

In petroleum systems, evaporite rocks play a fundamental role, mainly associated with pre-salt and sub-salt reservoirs, where they can act as seals, preventing the migration of hydrocarbons and contributing to the formation of stratigraphic traps, because of their movement and deformation (Jackson, 1995; Warren, 2016; Jackson \& Hudec, 2017). Another role that they can play is the creation of shallow areas as they move upward. Carbonate banks can develop on these areas (Vendeville \& Jackson, 1992).

Kirkland \& Evans (1981) and Schreiber (1988) observed that deposition of modern evaporites is associated with high levels of biological activity. They proposed that such levels of activity control, at least in part, the generation of hydrocarbons found in past analogues. The evaporite layer also plays another key factor in oil systems, which is directly associated with the success of exploration, because its thermal conductivity facilitates heat dissipation and allows organic matter to remain in the oil generation window for a longer time (Mello et al., 1995).

The evaporitic layers can represent a great challenge for hydrocarbons exploration. As the salts have capacity to deform significantly, which may allow them to flow into the well and replace the drilling mud, especially at high temperatures, putting the whole operation at risk (Perez et al., 2008). In many cases, a small deformation of the evaporitic layer may cause a decrease in well diameter or erroneous calibration, which leads to tube binding and to coating collapse (Barker et al., 1994).

The refractions and diffractions generated by the evaporitic layers can negatively affect seismic imaging. Studies focusing on solutions for this phenomenon have been of great importance for pre-salt imaging (Griffiths et al., 2011; Ji et al., 2011; Gobatto et al., 2016). Another challenge is the generation a top salt surface able to take into account the halokinesis-related deformations, which can have several points of the same latitude and longitude with multiple depth values, called multi- $z$ points (Zlatanova \& Prosperi, 2005).

The aim of this paper is to present a workflow to solve the problems of generating of a surface with multiple points in the $z$ axis and the zoning of the main salt structures. For this, the top of the evaporitic layer was interpreted, and the main structures 
generated by the halokinesis were identified as well as their influence in relation to the deformations in post-salt rocks and the seismic imaging in a distal area in the Santos Basin. For the generation of top salt surface, we used the integration of velocity model, as a guide, and the seismic interpretation, thus generating a more realistic surface that considers the salt structures such as mini-basins, overhangs and salt tongues.

\section{IDENTIFICATION AND ANALYSIS OF THE MAIN SALT STRUCTURES IN THE STUDY AREA}

The evaporitic layers constitute a group of unusual rocks, which contribute to the formation of structures with peculiar characteristics, that can intrude and deform adjacent and overlapping layers. In the study area, several features and structures of salt tectonics can be identified. Figure 1 shows a large diapir with four kilometers thick which, due to its movement towards the upper layers, has its top in discordant contact with the layers near the seafloor. In several locations a significant upwelling of salt structures occurs and the diapirs are almost in contact with the seafloor.

Salt wall features were also observed, as illustrates Figure 2, which are about thirty kilometers long and in some places

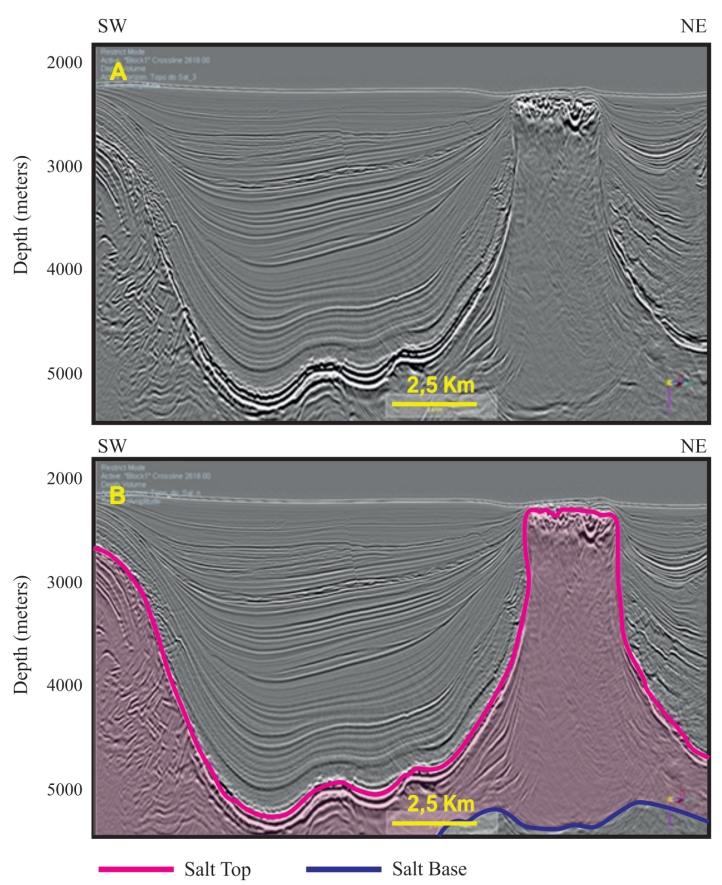

Figure 1 - Seismic section showing an example of a salt diapir: (A) uninterpreted section; and (B) interpreted section. Note the magnitude of the diapirs that can reach more than 3000 meters in height. four kilometers thick. In Figure 3, it is possible to observe an example of a feature generated by the halokinesis, called salt tongue, having a length of approximately ten kilometers. It is typically formed by lateral salt movement towards regions of lower pressure, usually through thrust faulting. The seismic facies of this salt tongues are represented by an intense intercalation of high-amplitude reflectors, characterized as stratified evaporitic layer. Sub-salt sediments can be seen below this structure and, in some cases, it is not possible to observe the continuity of top salt reflector as well as lower layers reflectors.

Due to the strong halokinesis, features of more distal areas, large sediment tongues occur between two thick salt packages, generating even salt windows in these places (Fig. 4). With the salt intrusion and movement, post-salt layers may also be deformed, fractured and/or faulted. From the tensions generated by the halokinesis, complex structures are formed, such as: anticlines, synclines and rotated blocks (Fig. 5). In some areas close to the salt dome tops, due to the influence of the salt tectonics, the presence of chaotic seismic facies is observed, without correlation with the laterally associated sediments (Fig. 6). This fact is probably related to the local tension generated by salt movement, as well as the heating of these areas due to the "chimney effect" (Warren, 2016). Seismic imaging below these

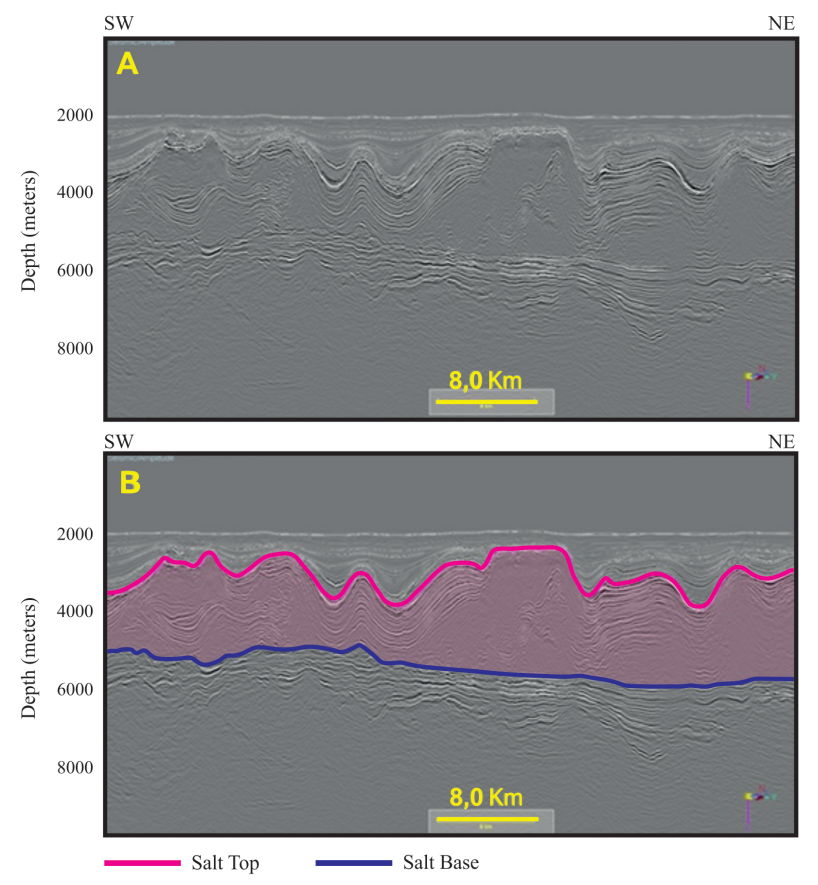

Figure 2 - Seismic section along the strike of the basin showing a gigantic salt wall: (A) uninterpreted section; and (B) interpreted section. 

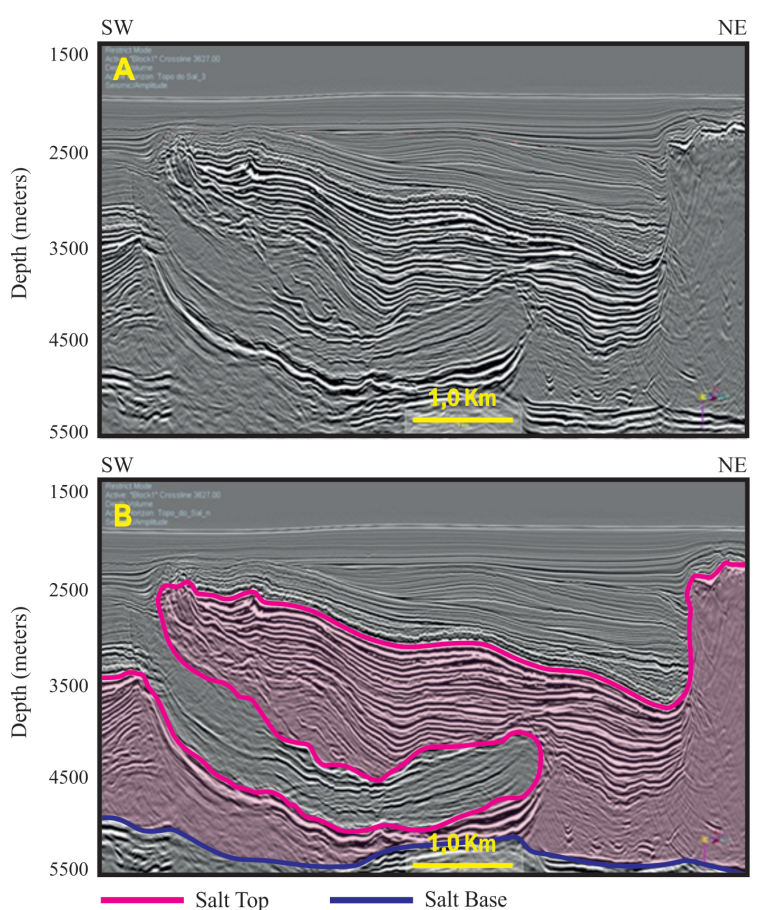

Figure 3 - Seismic section showing an example of a salt tongue: (A) uninterpreted section; and (B) interpreted section.

walls is impaired and, therefore, in many places it is not possible to clearly identify the reflector referring to the salt base.

Another structure interpreted in several regions of the study area was mini-basins. They are a confined space among the flanks of the diapirs formed by the deposition of sediments of greater density than the halite, being one of the causes of salt ascension and generation of accommodation space. Figure 7 shows an area with a mini-basin between two salt diapirs and inside salt strata it is also possible to observe stratification and even an angular unconformity within salt layers.

\section{GENERATION OF THE TOP SALT SURFACE: DIFFICULTIES AND SOLUTIONS}

Two interpretations of evaporite layer top were made: one simplified and one more detailed. In the simplified initial interpretation, complex salt overlapping and diapirism features were disregarded. This interpretation was performed to identify the main tendencies of top salt surface, thus ignoring the interpretation of points in depth with the same latitude and longitude (multi-z).

After the observation of the initial trends of the top of the evaporite layer, a more detailed analysis of the area was realized

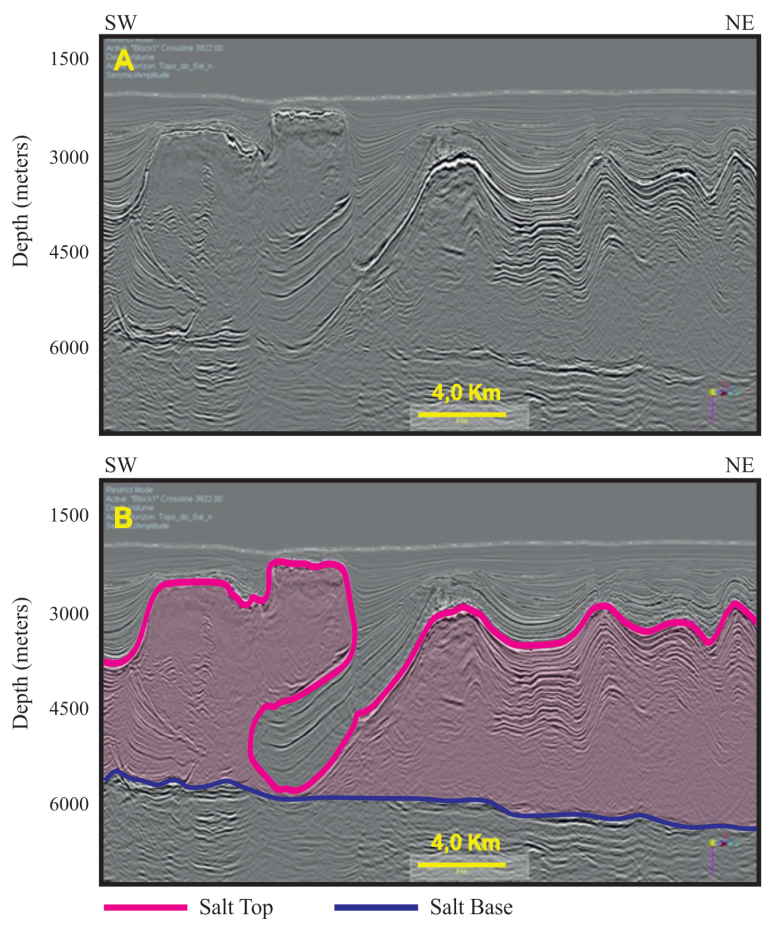

Figure 4 - Seismic section showing an example of overhang: (A) uninterpreted section; and (B) interpreted section.

and the influence of the halokinesis in the generation of complex structural features of the evaporite layer was considered in order to perform a more coherent and trustworthy interpretation. In this interpretation, the velocity model used in seismic migration aided the identification of salt structures (Fig. 8). In detailed analyses, the interpreted points have multiple values in depth with the same latitude and longitude (multi-z), reflecting structures such as salt tongues and overhangs. Even though some software suites can interpolate multi- $z$ interpretations converting them to grid surfaces, these resulting surfaces cannot be used as inputs for geological model grid construction due to the size of the generated file. In other words, they can only be used for visualization purposes.

The generation of the interpolated surfaces was done, in the case of simple interpretation, by minimum curvature gridding algorithm (Smith \& Wessel, 1990) and, in the case of detailed interpretation, by the Delauney triangulation method (Viviani \& Manzato, 2005). However, several attempts were made using different parameters for the interpolation of manually interpreted sections and in all these attempts, it was not possible to achieve any top salt surface consistent enough with the interpretation of the complex structures generated by the halokinesis, as can 

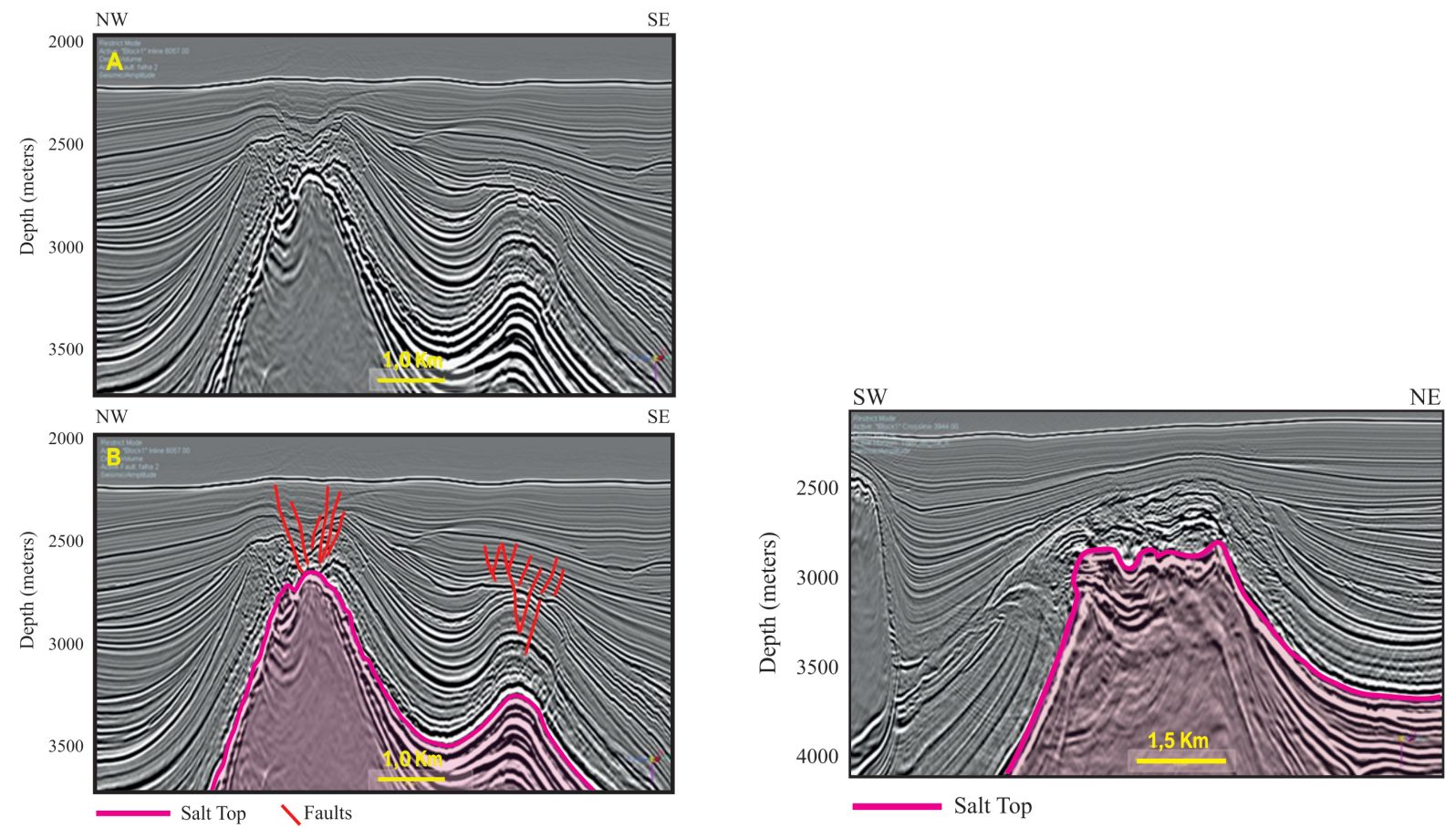

Figure 5 - Seismic section showing anticlinal and synclinal structures and many post-salt faults caused by halokinesis: (A) uninterpreted section; and (B)

Figure 6 - Chaotic seismic facies above the top salt. interpreted section.
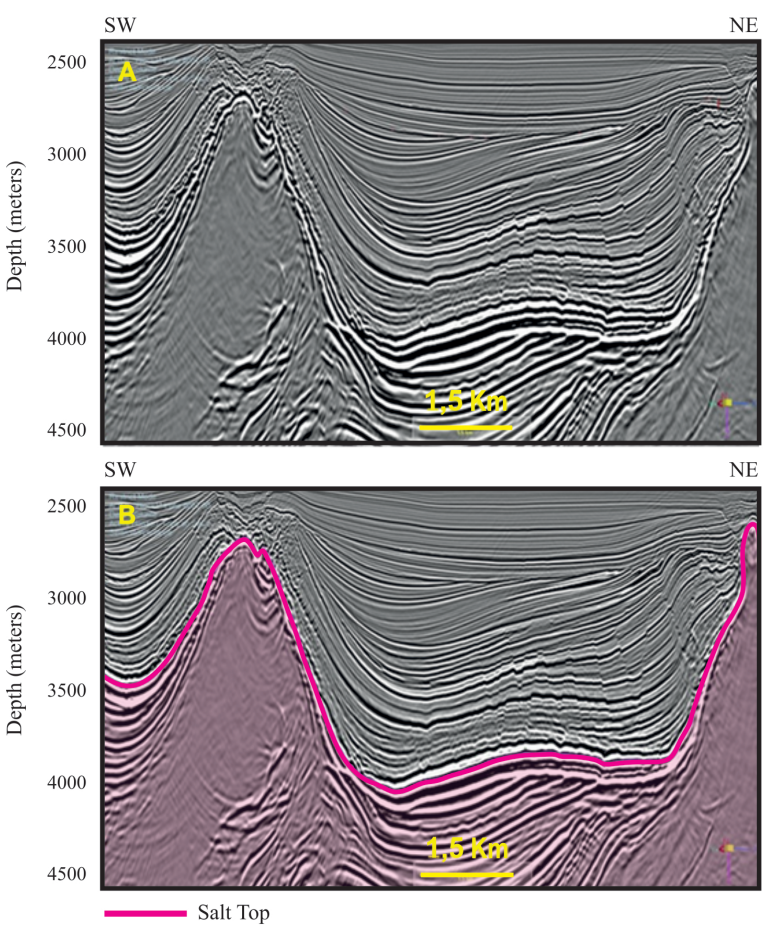

Figure 7 - Seismic section showing an example of mini-basins, salt stratification and angular unconformity among salt layers: (A) uninterpreted section; and (B) interpreted section. 


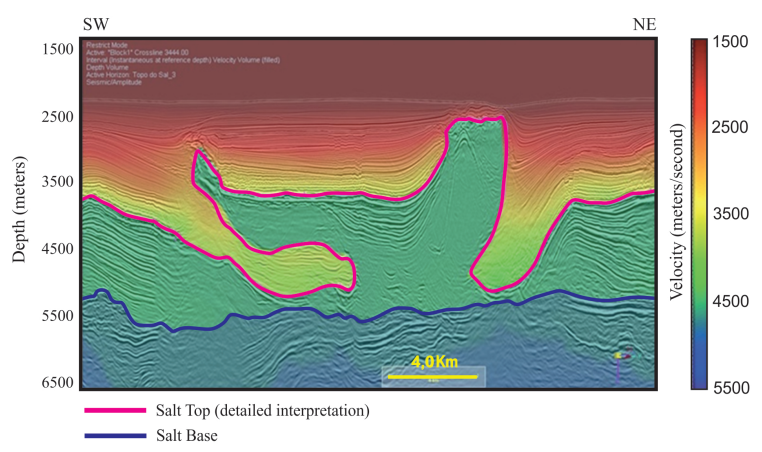

Figure 8 - The velocity model used in the seismic migration of the data with the detailed interpretation of the top salt.

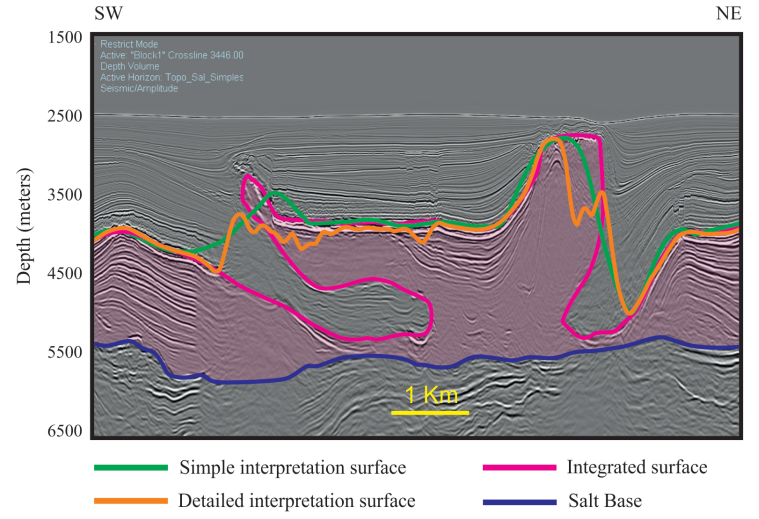

Figure $\mathbf{9}$ - Surfaces generated by the interpolation of simple interpretation (green), by the detailed interpretation (orange) and by the proposed method (purple).

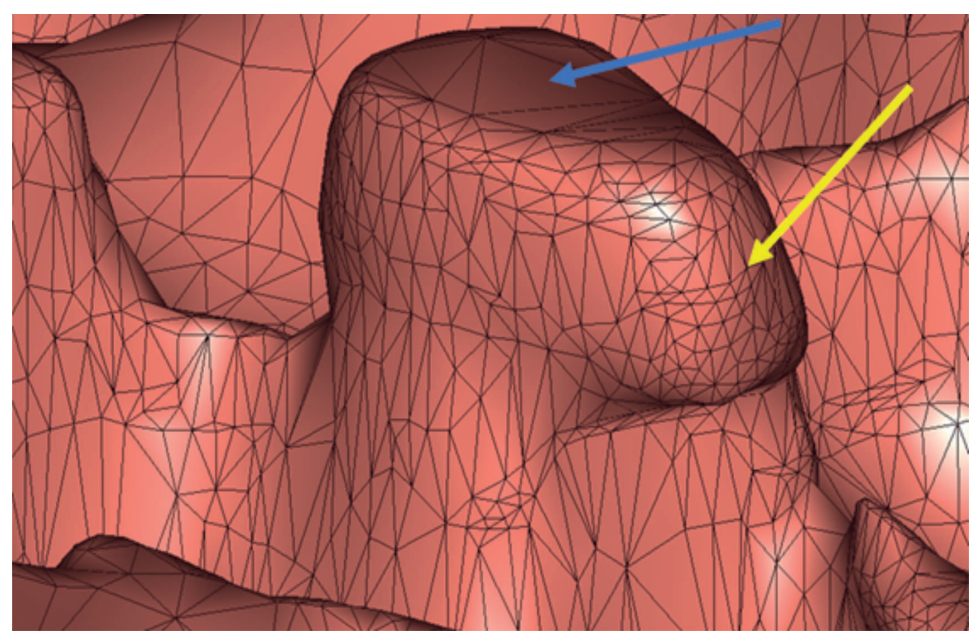

Figure 10 - Example of the triangulation procedure. Note that in the more complex areas require a greater amount of triangulation (yellow arrow), while in less complex areas there is no need for large amounts of triangulation (blue arrow).

be seen in Figure 9. The alternative solution was to generate a more reliable top salt surface to extract an iso-velocity curve of $4,500 \mathrm{~m} / \mathrm{s}$ directly from the velocity model, this value corresponds to the average velocity of halite in the study area. This surface extracted from the velocity model was then refined using the detailed seismic interpretation. The refinement was done by modifying the iso-velocity surface points manually where the salt structures were not yet well represented. This method brought greater accuracy for the generated surface and agility to the process. In Figure 9, it is also possible to note how the integrated surface of the top salt is much more coherent with the complex features.
The surface generated through the integration of the velocity model and the interpretation resulted in a very extensive file to be used in geological modeling and in the illumination study. The alternative was to reduce the file size by diminishing the number of points in the less complex areas, that is, a greater number of vertices and points were used only in more complex areas, as shown in Figure 10.

Finally, Figure 11 highlights the difference, in map view, between the triangulated surface from the simple interpretation and the surface obtained from the proposed method. In these maps, it is possible to perceive that the surface generated using 
a)

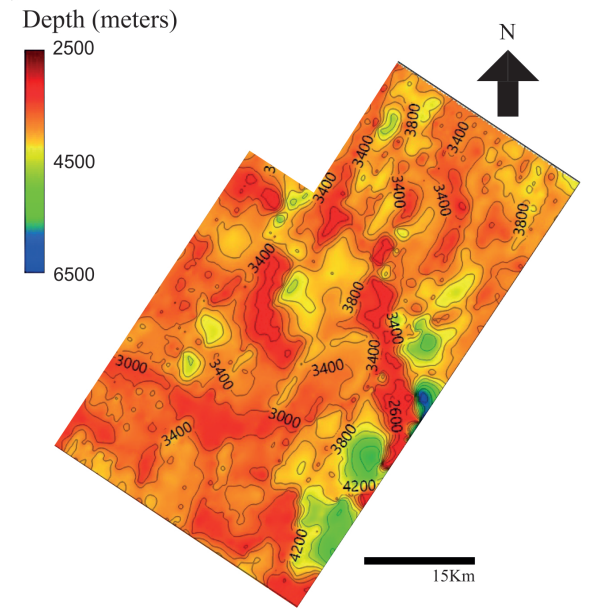

b)

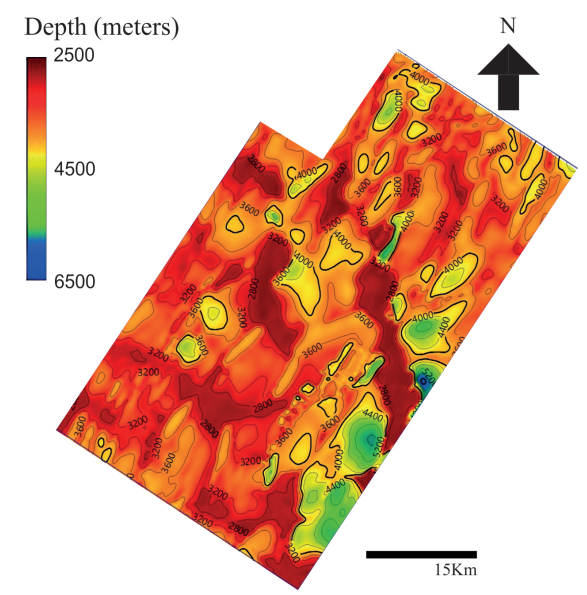

Figure 11 - a) Surface generated by the interpolation of the simple interpretation; b) Surface generated by the integrated method.

the proposed workflow has a much higher level of detail to represent complex salt features.

\section{ZONING OF STRUCTURES GENERATED BY HALOKINESIS}

Figure 12a shows the evaporite layer difference map in the study area generated from the top and base surfaces of the salt. It is important to note that it is not a thickness map since, especially in salt tongues, overhangs areas and salt windows below those structures, salt thickness is overestimated. However, the map still allows us to qualitatively infer about salt structures. It is possible to find regions of salt windows and areas with evaporitic layer a)

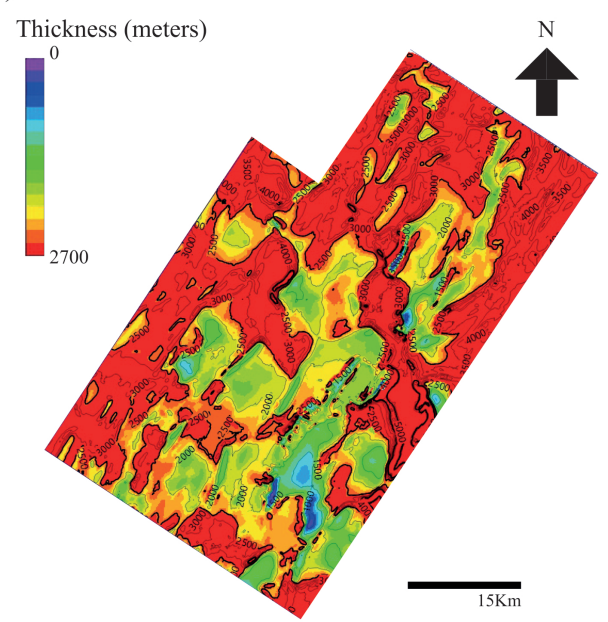

b)

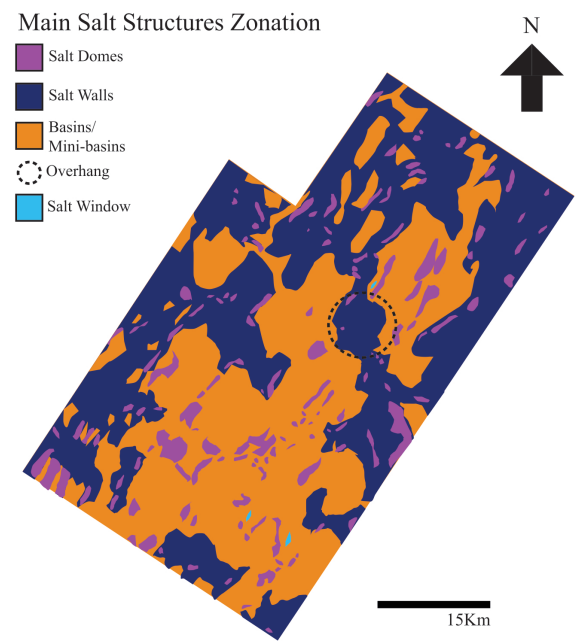

Figure 12 - a) Isopach map of the evaporites (the color palette was restricted at its maximum in 2700 meters for better visualization of salt features); b) Zonation map of structures formed by the halokinesis in the study region.

thicknesses that reach up to more than 4 kilometers. Figure $12 \mathrm{~b}$ presents the result of zonation of the areas where each of the features generated by the effects of the halokinesis exists. Due to occurrence of structures of salt tongues and walls, it is possible to infer that the study area is in a region of salt tectonic compressive regimen under main gravitational tectonics.

\section{CONCLUSION}

We identified the influences of the salt tectonics on post-salt formations, which can generate discordant layers of saline body structures, anticlines and synclines above the domes and several faults and fractures. Due to the complexity of the horizon 
interpreted from the top salt, a reliable interpolation becomes infeasible even with a dense mesh of manual interpretation. The proposed methodology using the velocity model as a guide and then manually refining with the detailed interpretation of salt structures was effective in creating a surface coherent with the actual salt forms in the study area. And finally, the zoning of the main structures generated by the halokinesis allowed the definition of the main domes, salt walls, mini-basins and overhangs generated by the salt movement and the existence of salt windows in the studied area.

\section{ACKNOWLEDGEMENTS}

The authors thank the Petrogal Brasil and Agência Nacional do Petróleo, Gás Natural e Biocombustíveis (ANP) for providing the field dataset and financial support for this research.

\section{REFERENCES}

ALVES TM, FETTER M, LIMA C, CARTWRIGHT JA, COSGROVE J, GANGÁ A, QUEIROZ CL \& STRUGALE M. 2017. An incomplete correlation between pre-salt topography, top reservoir erosion, and salt deformation in deep-water Santos Basin (SE Brazil). Marine and Petroleum Geology, 79: 300-320.

BARKER JW, FELAND K \& TSAO YH. 1994. Drilling long salt sections along the US Gulf Coast. SPE Drilling \& Completion, 9(03): 185-188.

DA SILVA MA, SCHREIBER BC \& DOS SANTOS CL. 2018. Evaporitos como recursos minerais. Revista Brasileira de Geofísica, 18(3): 337-350.

DAVISON I, ANDERSON L \& NUTTALL P. 2012. Salt deposition, loading and gravity drainage in the Campos and Santos salt basins. Geological Society, London, Special Publications, 363(1): 159-174.

DEMERCIAN S, SZATMARI P \& COBBOLD P. 1993. Style and pattern of salt diapirs due to thin-skinned gravitational gliding, Campos and Santos basins, offshore Brazil. Tectonophysics, 228(3-4): 393-433.

DOOLEY TP, JACKSON MP, JACKSON CAL, HUDEC MR \& RODRIGUEZ CR. 2015. Enigmatic structures within salt walls of the Santos Basin-Part 2: Mechanical explanation from physical modelling. Journal of Structural Geology, 75: 163-187.

GAMBOA L, MACHADO MP, DA SILVEIRA D, DE FREITAS J, DA SILVA S, MOHRIAK W, SZATMARI P \& ANJOS S. 2008. Evaporitos estratificados no Atlântico Sul: interpretação sísmica e controle tectono-estratigráfico na Bacia de Santos. In: MOHRIAK W, SZATMARI P \& ANJOS SMC (Org.). Sal: Geologia e Tectônica, Exemplos nas Bacias Brasileiras, São Paulo, Brazil: Editora Beca. p. 340-359.

GOBATTOF, MAUL A, TEIXEIRA L, GONZÁLEZ G, FALCÃO L, GONZÁLEZ M \& BOECHAT JT. 2016. Refining velocity model within the salt section in Santos Basin: An innovative workflow to include the existing stratification and its considerations. In: SEG Technical Program Expanded Abstracts 2016. p. 5328-5333. Society of Exploration Geophysicists.

GRIFFITHS M, HEMBD J \& PRIGENT H. 2011. Applications of interbed multiple attenuation. The Leading Edge, 30(8): 906-912.

GUERRA MC \& UNDERHILL JR. 2012. Role of halokinesis in controlling structural styles and sediment dispersal in the Santos Basin, offshore Brazil. Geological Society, London, Special Publications, 363(1): 175-206.

JACKSON CAL, JACKSON MPA, HUDEC MR \& RODRIGUEZ CR. 2015. Enigmatic structures within salt walls of the Santos Basin-Part 1: Geometry and kinematics from 3D seismic reflection and well data. Journal of Structural Geology, 75: 135-162.

JACKSON MPA. 1995. Retrospective salt tectonics. AAPG Special Volumes. $454 \mathrm{pp}$.

JACKSON MPA \& HUDEC MR. 2017. Salt tectonics: Principles and practice. Cambridge University Press. 494 pp.

JI S, HUANG T, FU K \& LI Z. 2011. Dirty salt velocity inversion: The road to a clearer subsalt image. Geophysics, 76(5): WB169-WB174.

KARNER G \& GAMBÔA L. 2007. Timing and origin of the South Atlantic pre-salt sag basins and their capping evaporites. Geological Society, London, Special Publications, 285(1): 15-35.

KIRKLAND DW \& EVANS R. 1981. Source-rock potential of evaporitic environment. AAPG Bulletin, 65(2): 181-190.

MELLO UT, KARNER GD \& ANDERSON RN. 1995. Role of salt in restraining the maturation of subsalt source rocks. Marine and Petroleum Geology, 12(7): 697-716.

MODICA CJ \& BRUSH ER. 2004. Postrift sequence stratigraphy, paleogeography, and fill history of the deep-water Santos Basin, offshore southeast Brazil. AAPG Bulletin, 88(7): 923-945.

MOHRIAK W, NEMC OK M \& ENCISO G. 2008. South Atlantic divergent margin evolution: rift-border uplift and salt tectonics in the basins of SE Brazil. Geological Society, London, Special Publications, 294(1): 365-398.

MOHRIAK W, SZATMARI P \& ANJOS SMC. 2009. Sal: Geologia e Tectônica; Exemplos nas Bacias Brasileiras. Terrae Didatica, 4(1): 90-91.

MOREIRA JLP, MADEIRA CV, GIL JA \& MACHADO MAP. 2007. Bacia de Santos. Boletim de Geociências da Petrobras, 15(2): 531-549.

PEREZ MA, CLYDE R, D'AMBROSIO P, ISRAEL R, LEAVITT T, NUTT L, JOHNSON C \& WILLIAMSON D. 2008. Meeting the subsalt challenge. Oilfield Review, 20(3): 32-45.

SCHREIBER BC. 1988. Evaporites and hydrocarbons. Volume 488. Columbia University Press, New York. 475 pp. 
SMITH W \& WESSEL P. 1990. Gridding with continuous curvature splines in tension. Geophysics, 55(3): 293-305.

VENDEVILLE BC \& JACKSON MP. 1992. The rise of diapirs during thin-skinned extension. Marine and Petroleum Geology, 9(4): 331-354.

VIVIANI E \& MANZATO GG. 2005. Geração de modelos digitais de superfície por meio de plataformas computacionais com estrutura vetorial e raster. Ciencia y Engenharia/Science and Engineering Journal, 14(2): 27-33.

WARREN JK. 2016. Evaporites: A Geological Compendium. Switzerland: Springer. $1813 \mathrm{pp}$.

ZLATANOVA S \& PROSPERI D. 2005. Large-Scale 3D data integration: challenges and opportunities. Boca Raton: CRC Press. 240 pp.

Recebido em 18 de novembro de 2018 / Aceito em 15 de maio de 2019

Received on November 18, 2018 / Accepted on May 15, 2019 